\title{
Patches of the mussel Mytilus sp. are islands of high biodiversity in subtidal sediment habitats in the Baltic Sea
}

\author{
Pia Norling*, Nils Kautsky \\ Department of Systems Ecology, Stockholm University, Se-106 91 Stockholm, Sweden
}

\begin{abstract}
Mytilus sp. is a habitat-modifying species that can influence biodiversity by facilitation and inhibition of species. We investigated the relationship between size of Mytilus patches, sediment characteristics and species richness of associated macrofauna, meiofauna and macroalgae on sandy sediments at $7 \mathrm{~m}$ depth in the Askö area, northern Baltic proper. A total of 24 associated macrofauna species were identified, 11 of which were not present on bare sediment outside the patches. The bare sediment had on average 5 species, which increased to 6 associated species at a mussel patch size of $5 \mathrm{~cm}^{2}$ and 17 species at $314 \mathrm{~cm}^{2}$, which was $>85 \%$ of the associated species in a nearby large mussel bed. The diversity of macro-infauna was higher in mussel patches compared to sediment. Macroalgae, being dependent on mussel shell as substrate or on attachment by byssus threads, were not found outside patches. Sediment contents of total carbon and nitrogen were significantly higher within patches than outside, mainly due to the mussels' filtration and biodeposition of small nutrientrich particles. Diversity of meiofauna did not change with patch size, but total abundance of Nematoda was higher within patches. As patch size increased, the effects of Mytilus on the sediment characteristics became stronger, but few negative effects of increased biodeposition were seen on species richness. The results show that mussel patches represent islands of high biodiversity in sediment areas and belong to the most species-rich habitats in the Baltic Sea, due to structural and functional effects.
\end{abstract}

KEY WORDS: Engineering species $\cdot$ Patch size $\cdot$ Facilitation $\cdot$ Community structure $\cdot$ Biodiversity Associated species $\cdot$ Ecological role $\cdot$ Habitat modification

\section{INTRODUCTION}

In marine benthic systems, community structure and ecosystem functions are often dependent on particular species that modify and create highly diverse habitats (Bruno \& Bertness 2001). By creating spatial refuges from environmental stress and/or predation, primary spaceholders can generate and maintain local species diversity (Witman 1985, Hacker \& Gaines 1997). Recent research demonstrates strong effects of facilitation, due to the influence of organismal traits on ecosystem processes, on species composition and diversity at population and community level, as well as at landscape scale (Bruno et al. 2003).
Mussels are such habitat modifiers (Dayton 1972), or engineering species (Jones et al. 1994), which by altering the environmental properties facilitate the presence of species that would otherwise be absent (e.g. Crooks 1998, Ragnarsson \& Raffaelli 1999) or inhibit the presence of and/or exclude others (Commito 1987, Beadman et al. 2004). The mussel shells provide secondary hard substratum, which in sedimentary habitats may be the only hard substratum available for settlement of sessile organisms and algae (Albrecht 1998, Buschbaum 2000).

In contrast to other habitat modifying organisms, such as kelp and seagrass, mussels not only provide habitat structure and shelter, but also clear the water 
by filter feeding, regenerate nutrients that benefit algae (Kautsky \& Wallentinus 1980) and increase rates of sedimentation through biodeposition of organically enriched faeces and pseudo-faeces providing food for deposit feeders (Kautsky \& Evans 1987, Norkko et al. 2001). Mussels can thus supply the associated community with 24 to $31 \%$ of its energy demand (Norling \& Kautsky 2007). The changed near-bed hydrodynamic regime caused by the presence of the mussels allows the accumulation of finer organic particles (Widdows et al. 1998, Gutiérrez et al. 2003), leading to a modified habitat, which sometimes can have negative effects on infauna by causing low oxygen and high sulphide levels in the sediment (Dittmann 1990, Ragnarsson \& Raffaelli 1999, Commito \& Dankers 2001).

Mytilid mussels form beds or patches composed of layers of mussels with accumulated sediment, faeces, pseudo-faeces and shell debris, making up a mussel matrix, on substrata ranging from muddy soft bottoms to exposed hard bottoms. The ecology and biodiversity of Mytilus edulis beds and patches have been subjected to a number of studies (see reviews by Commito \& Dankers 2001, Thiel \& Ullrich 2002, Chintiroglou et al. 2004) and the diversity of associated macrofauna has been found to increase with age and size of mussel patches (Tsuchiya \& Nishihira 1985, 1986, Norling \& Kautsky 2007), and decrease with increasing tidal elevation (Tsuchiya \& Retière 1992, Saier 2002). However, for subtidal environments and sediment habitats, information is generally lacking, and studies of the relationship from sediment habitats have been rather inconclusive regarding minimum patch size when effects occur (e.g. Svane \& Setyobudiandi 1996), probably due to the narrow size range studied. Furthermore, most of the studies were carried out in marine areas, while in the brackish Baltic Sea there has only been a single study on meiofauna diversity in mussel beds (Radziejewska 1986).

In the species-poor Baltic Sea, Mytilus cf. edulis is, due to lack of predators and competitors for space, a dominant species on sublittoral hard substrates down to $30 \mathrm{~m}$ depth (Kautsky 1982, Kautsky et al. 1990) and is also very common on sublittoral soft bottoms in the Baltic proper (Ankar \& Elmgren 1976), making up a total of 50 to $80 \%$ of the shell-free animal biomass in the coastal zone in the Baltic proper (Kautsky \& Kautsky 1995). The mussels found here are dwarfed by salinity stress and were for a long time believed to be a separate species. However, recent studies show that $M$. edulis and $M$. trossulus hybridise in the Baltic (Kijewski et al. 2006); therefore we will hereafter call them Mytilus.

The aim of the present study was to evaluate the importance of Mytilus for the biodiversity (species richness and composition) of Baltic Sea sublittoral sedi- ment habitats, and investigate how this is influenced by Mytilus patch size. Patch sizes ranging from single mussels to an entire mussel bed were compared to bare sediment bottoms without mussels, in order to assess the relationship between patch area, sediment characteristics, biodiversity of associated macrofauna, meiofauna and macroalgae. We hypothesised that Mytilus would have facilitating effects on species richness and abundance with increasing patch size above the sediment surface, and inhibiting effects in the sediment beneath the mussel patches. Therefore, the epifauna and infauna communities associated with Mytilus, living within the mussel matrix and beneath the sediment surface, were investigated separately.

\section{MATERIALS AND METHODS}

The studies were conducted at Persö, in the Askö Archipelago (58 $\left.47.612^{\prime} \mathrm{N}, 17^{\circ} 36.080^{\prime} \mathrm{E}\right)$, Baltic proper, in September 2003. The salinity in the area was $6.1 \mathrm{psu}$, and the tidal range is only $2 \mathrm{~cm}$. The patchiness of the area was on average approximately $30 \mathrm{~cm}$ between well-separated patches, and was dominated by smaller patches (25 to $225 \mathrm{~cm}^{2}$ ) and few large patches $\left(>1 \mathrm{~m}^{2}\right)$, which were all randomly arranged on the soft sediment. In the study of the mussel matrix community, Mytilus patch assemblages ( $\mathrm{n}=12)$ with sizes ranging from 5 to $314 \mathrm{~cm}^{2}$ were sampled at 7 to $8 \mathrm{~m}$ depth using SCUBA. The whole mussel patches, including associated fauna and flora were collected by scraping off the $1 \mathrm{~cm}$ top layer of sediment within $20 \times$ $20 \mathrm{~cm}$ quadrats $\left(400 \mathrm{~cm}^{2}\right)$ and frozen before biodiversity determination. The patch diameters were measured with a ruler and the patch areas were then calculated. Macrofauna samples $(n=5)$ were also collected from a nearby large mussel bed of $4 \mathrm{~m}^{2}$ using the same $20 \times 20 \mathrm{~cm}$ frames in the same way, as well as in an adjacent bare sediment area without mussels (approximately $3 \mathrm{~m}$ away) representing the sediment control $(\mathrm{n}=5)$. In a second sampling focusing on the infauna community, core samples were collected from mussel patches ranging from 4 to about $28000 \mathrm{~cm}^{2}(\mathrm{n}=22)$ and from bare sediment $(\mathrm{n}=15)$ by using Plexiglass cores $(\varnothing=10 \mathrm{~cm})$. The top $1 \mathrm{~cm}$ was removed before $10 \mathrm{~cm}$ sediment core sample was sliced off and sieved through 2, 1 and $0.5 \mathrm{~mm}$ meshes. All macrofauna and macroalgae were identified to species level and dried at $60^{\circ} \mathrm{C}$ to constant weight.

In the first sampling, duplicate sediment samples for study of meiofauna and sediment characteristics were collected inside and approximately $30 \mathrm{~cm}$ outside of each mussel patch, as well as in the bare sediment control area $(n=12)$ and in the mussel bed $(n=5)$, using small sediment cores $(\varnothing=2.6 \mathrm{~cm})$. The surface sedi- 
ment layer ( 0 to $2 \mathrm{~cm}$ ) from 1 of each duplicate was preserved in $4 \%$ formalin for meiofauna studies and the other was used for sediment characterisation and chemical analysis. Meiofauna were extracted by diluting the sediment with tap water and repeatedly stirring and decanting of the supernatant through a set of sieves with 0.040, 0.100 and $1 \mathrm{~mm}$ mesh size (Dybern et al. 1976). The samples were stained with Bengal rose before being identified and counted under a dissecting microscope. The $100 \mu \mathrm{m}$ fractions were used in the diversity studies where only the molluscs were identified to species level. The rest of the fauna was identified to higher taxa. The sediment was weighed and then dried at $60^{\circ} \mathrm{C}$ to constant weight for determination of water content. Ash-free dry weights of the sediments were determined after ashing at $500^{\circ} \mathrm{C}$ for $12 \mathrm{~h}$ and loss on ignition (LOI) was calculated from the weight loss. Carbon and nitrogen analyses were done with a LECO Elemental Analyser (model CHNS-932) and were run in duplicate.

Statistical methods. In the first sampling, the species richness of macrofauna in the mussel patches was analysed using nonlinear regression (NR) according to Peake \& Quinn (1993) in order to evaluate the relationship between number of species and patch area. A power function was fitted by using a modified GaussNewton method (Quasi-Newton):

$$
\text { Number of species }=\alpha(\text { area })^{\beta}
$$

in accordance to Quinn \& Keough (2002). The relationships between species richness and patch area for macroalgae and meiofauna were also tested using NR.

The patches were also treated as discrete size classes: small patches ( $>1$ to $44 \mathrm{~cm}^{2}$ ), medium patches ( 79 to $154 \mathrm{~cm}^{2}$ ) and large patches $\left(254\right.$ to $314 \mathrm{~cm}^{2}$ ) for analysis, which were chosen a priori by the most common patch sizes in the area. For comparison of species richness and biomass for macrofauna, macroalgae and functional groups between the control, mussel bed and the different patch size classes, small, medium and large patches were tested with 1-way ANOVA and post hoc Student-Newman-Keuls (SNK) test. Homogeneity of variances was tested with Cochran's $C$-test. To meet the homogeneity requirement, the abundance data were transformed. The same tests were used for meiofauna species richness and abundance between different sampling positions: control area, outside $(30 \mathrm{~cm})$ and inside mussel patches.

The relationship between patch size and macroalgae biomass was tested with Spearman's rank correlation, since the relationship was undefined and there were many zeros in the dataset. Relationships between patch size, meiofauna abundance and organic content (LOI) in the sediment were tested with a simple linear model, LR. The differences in organic content in sedi- ment between different sampling positions were tested with 1-way ANOVA.

In the second sampling, differences in species richness of macro-infauna beneath mussel patches and in bare sediment were tested with ANOVA. The relationship between patch size and species richness of infauna was tested with LR. All statistical analyses were performed using Statistica 6.0 (StatSoft).

\section{RESULTS}

\section{Mytilus size distribution}

There were small differences in Mytilus size distribution pattern among patches, and also compared to the nearby mussel bed (Fig. 1). The mussel sizes ranged from 1 to $35 \mathrm{~mm}$ in length, and individuals of 2 to $23 \mathrm{~mm}$ were represented in all patches. The average mussel size ranged between 8.6 and $13.3 \mathrm{~mm}$ and did not differ among patch size classes and the mussel bed.

\section{Macrofauna}

Mussel matrix community

The control area, mussel patches and mussel bed harboured $5 \pm 1,6$ to 17 , and $18.2 \pm 0.2$ species, respectively (Table 1 ). There was a strong positive relationship between Mytilus patch size and the associated macrofauna species richness, with data fitted to a power model (Fig. 2, Table 2). A total of 6 phyla and 22 associated species were found, 12 of which were not present outside the patches in the control on the bare sediment (Table 1). The maximum number of 17 species (excluding Mytilus) was found at the largest patch size of $314 \mathrm{~cm}^{2}$. The species richness curve flattens out with increasing size indicating that the species maximum for this Mytilus habitat was approached. In a nearby mussel bed, a maximum of 19 macrofauna species (excluding Mytilus) per $400 \mathrm{~cm}^{2}$ (n=5) was found.

There was a significant difference in macrofauna species richness (ANOVA, $F_{4,17}=61.7, p<0.001$ ) between the sediment control area, Mytilus patches and bed. In comparison to the average of $5 \pm 1$ species found in the sediment, all mussel samples harboured 6 or more species (excluding Mytilus).

The species richness was significantly higher in medium and large patches (SNK, $\mathrm{n}=4, \mathrm{p}<0.001$ and $\mathrm{p}<0.001$, respectively) compared to small patches. The smallest patches harboured an average of 9 species compared to an average of 14 species in the medium patches. This increase was due to an increase 

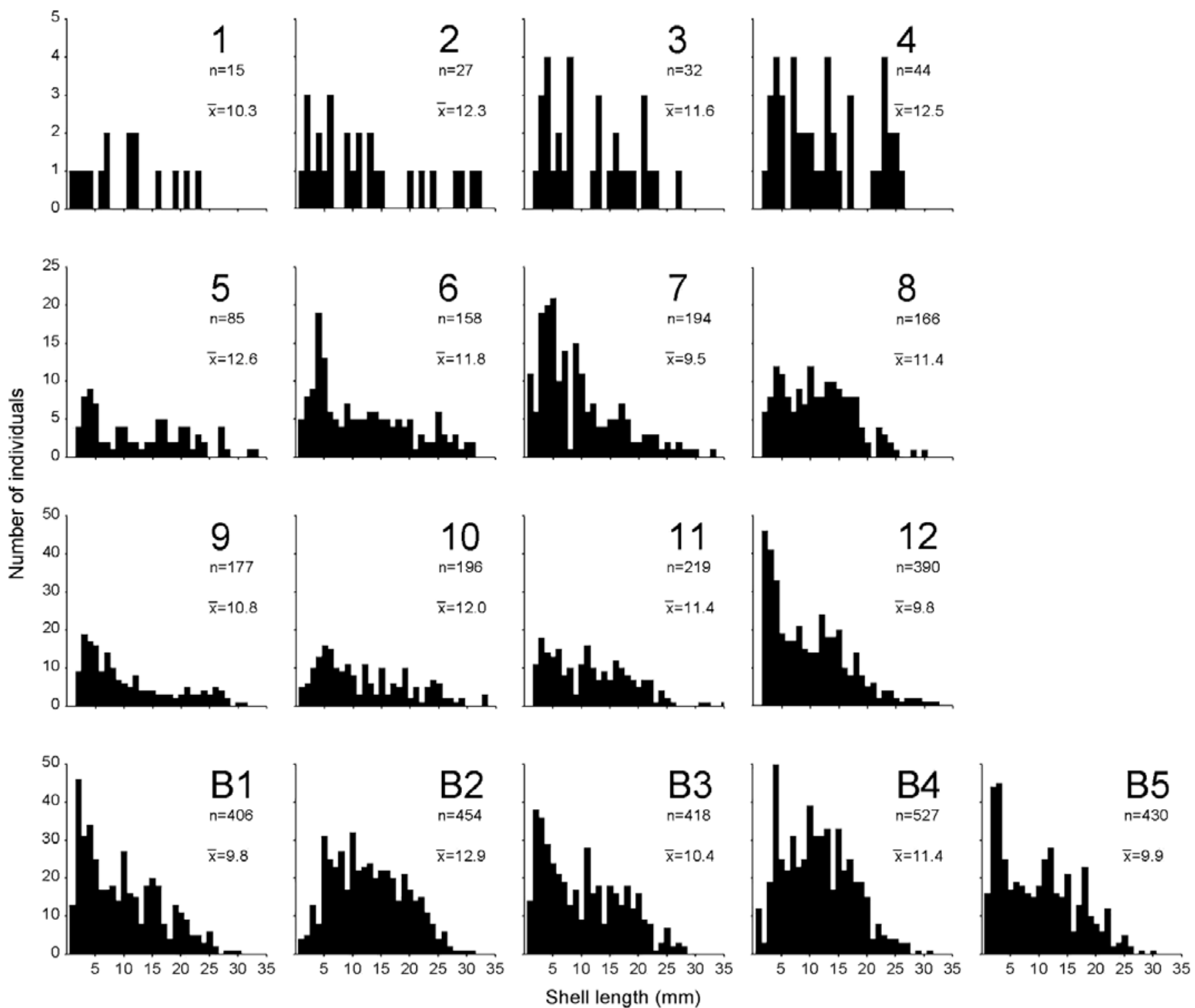

Fig. 1. Mytilus edulis. Size distribution in individual patches of different size (samples 1 to 12 , see Table 1) and mussel bed (samples B1 to B5). $\mathrm{n}=$ number of individuals, $\bar{x}=$ average shell size

in the number of species of Crustacea (Balanus improvisus, Gammarus oceanicus and Idothea viridis), Gastropoda (Limapontia capitata) and Oligochaeta (Clitellio arenarius) (Table 1). The mussel bed harboured the highest number of species compared to the mussel patches and this was significant for each comparison (SNK, $\mathrm{n}=4, \mathrm{p}<0.001$ for small, $\mathrm{p}=0.001$ for medium, $\mathrm{p}=0.002$ for large patches).

In terms of abundance, the associated macrofauna in mussel patches was dominated by Gastropoda (67 to $92 \%$ ) and Bivalvia (8 to $27 \%$ of total abundance) (Table 1), with few species from each taxonomic group. In the control area, Gastropoda (68\%) and Bivalvia $(32 \%)$ dominated, while Bivalvia only comprised on average $8 \%$ in the mussel bed, which otherwise had a high dominance of Gastropoda (89\%).

The total macrofauna abundance varied between $34 \times 10^{3}$ and $67 \times 10^{3}$ ind. $\mathrm{m}^{-2}$ in the patches. The mud snail Hydrobia ulvae was the most abundant species in all patches, followed by the cockle Cerastoderma glaucum. The cockle was mainly found at the surface of the sediment. Amphipoda and Isopoda, dominated by Gammarus salinus, G. oceanicus and Idothea baltica, were most abundant in the large patches. Black goby Gobius niger was only found in the largest patch and the adjacent mussel bed. Species dominant in the sediment control area were Macoma balthica, H. ulvae and Potamopyrgus antepodarum. 
Table 1. Abundances, species richness and biomass of associated macrofauna species in Mytilus patches of different sizes ( $\mathrm{N}=12$ ) and for a mussel bed and sediment control (mean $\pm \mathrm{SE}, \mathrm{n}=5$ ). The overall number of species found in mussel bed and sediment control was 21 and 10 , respectively. Functional groups of macrofauna were defined by feeding type. $F=$ filter feeder, Sur D = surface detritivore, Sub $D=$ subsurface detritivore, Mac $\mathrm{H}=$ macroalgae herbivore, Mic $\mathrm{H}=$ microalgae herbivore, $\mathrm{C}=$ carnivore, $\mathrm{O}=$ omnivore, $\mathrm{P}=$ parasite.+ indicates presence

\begin{tabular}{|c|c|c|c|c|c|c|c|c|c|c|c|c|c|c|c|}
\hline & Funct. group & 1 & 2 & 3 & 4 & 5 & 6 & 7 & 8 & 9 & 10 & 11 & 12 & Bed & Control \\
\hline \multicolumn{16}{|l|}{ Abundance $\left(10^{3}\right.$ ind. $\left.\mathrm{m}^{-2}\right)$} \\
\hline \multicolumn{16}{|l|}{ Nemertina } \\
\hline Cyanophthalma obscura & $\mathrm{C}$ & & 0.6 & & & 0.1 & 0.06 & 0.2 & 0.3 & 0.5 & 0.3 & 0.2 & 0.2 & $0.4 \pm 0.1$ & \\
\hline \multicolumn{16}{|l|}{ Oligochaeta } \\
\hline Clitellio arenarius & Sub D & & & & & 0.1 & 0.2 & 0.06 & & 0.03 & 0.1 & & & $0.1 \pm 0.01$ & $0.03 \pm 0.02$ \\
\hline Tubificoides benedii & Sub D & & 0.6 & & 0.4 & 0.1 & & 0.1 & 0.04 & 0.5 & 0.2 & 0.03 & 0.03 & $0.1 \pm 0.03$ & $0.01 \pm 0.01$ \\
\hline \multicolumn{16}{|l|}{ Polychaeta } \\
\hline Hediste diversicolor & $\mathrm{O}$ & & 0.6 & 0.4 & & 0.2 & 0.3 & 0.06 & 0.04 & 0.4 & 0.2 & 0.2 & 0.05 & $0.2 \pm 0.03$ & $0.03 \pm 0.01$ \\
\hline Pygospio elegans & Sur D & & & & 0.2 & & & & & & & 0.03 & & $0.06 \pm 0.02$ & $0.01 \pm 0.01$ \\
\hline \multicolumn{16}{|l|}{ Hirudinea } \\
\hline Piscicola geometra & $\mathrm{P}$ & & & & & & & & & & & & & $0.01 \pm 0.01$ & \\
\hline \multicolumn{16}{|l|}{ Gastropoda } \\
\hline Hydrobia ulvae & Sur D & 37 & 157 & 34 & 43 & 37 & 24 & 42 & 47 & 50 & 41 & 30 & 48 & $91 \pm 12$ & $6 \pm 1.4$ \\
\hline $\begin{array}{l}\text { Potamopyrgus } \\
\text { antepodarum }\end{array}$ & Sur D & 2 & 21 & 6 & 0.9 & 5 & 2 & 2 & 1 & 4 & 6 & 1 & 0.9 & $5 \pm 0.9$ & $0.9 \pm 0.6$ \\
\hline Lymnea peregra & Mic H & & & & & & & & & & & & 0.03 & & \\
\hline Theodoxus fluviatilis & Mic H & 3 & & 0.4 & 0.2 & 0.5 & 0.1 & 0.2 & 0.3 & 0.5 & 0.5 & 0.2 & 0.3 & $0.5 \pm 0.1$ & $0.1 \pm 0.06$ \\
\hline Limapontia capitata & Mac H & & & & & 0.1 & & 0.06 & & & 0.06 & 0.03 & & $0.04 \pm 0.02$ & \\
\hline \multicolumn{16}{|l|}{ Bivalvia } \\
\hline Cerastoderma glaucum & $\mathrm{F}$ & 13 & 17 & 13 & 3 & 19 & 7 & 8 & 5 & 10 & 10 & 5 & 4 & $7 \pm 0.9$ & $0.5 \pm 0.5$ \\
\hline Macoma balthica & Sub D & 3 & 2 & 0.4 & 3 & 0.7 & 0.8 & 0.8 & 0.6 & 1 & 1 & 0.5 & 0.5 & $1 \pm 0.3$ & $2.7 \pm 0.9$ \\
\hline Mya arenaria & $\mathrm{F}$ & & 0.6 & & & 0.1 & 0.06 & & & & & 0.03 & 0.03 & $0.01 \pm 0.01$ & $0.01 \pm 0.01$ \\
\hline \multicolumn{16}{|l|}{ Crustacea } \\
\hline Gammarus oceanicus & $\mathrm{O}$ & & & & & & & 0.1 & & 0.1 & & & 0.5 & $0.5 \pm 0.1$ & \\
\hline Gammarus salinus & $\mathrm{O}$ & & 0.6 & 0.4 & & 0.2 & 0.06 & 0.06 & 0.04 & 0.1 & 0.1 & 0.03 & 0.3 & $2 \pm 0.2$ & \\
\hline Gammarus juv. & $\mathrm{O}$ & & & & & & & & & & & & & $0.1 \pm 0.02$ & \\
\hline Idothea baltica & Mac H & & & 0.4 & 0.2 & & & & 0.09 & 0.1 & & & 0.3 & $0.3 \pm 0.1$ & \\
\hline Idothea viridis & Mac H & & & & & 0.2 & 0.06 & 0.4 & 0.04 & & 0.03 & & 0.1 & $0.02 \pm 0.01$ & \\
\hline Jaera albifrons sp. & Mic $\mathrm{H}$ & 1.7 & & & & 0.1 & & & & & & & & $0.02 \pm 0.01$ & \\
\hline Balanus improvisus & $\mathrm{F}$ & & & & & & 0.06 & & & & 0.03 & 0.03 & 0.05 & $0.1 \pm 0.01$ & \\
\hline Electra crustulenta & $\mathrm{F}$ & & + & + & + & + & + & + & + & + & + & + & + & + & \\
\hline \multicolumn{16}{|l|}{ Chordata } \\
\hline Gobius niger & $\mathrm{C}$ & & & & & & & & & & & & 0.03 & $0.01 \pm 0.01$ & \\
\hline \multicolumn{2}{|l|}{ Total abundance $\left(10^{3}\right.$ ind. $\left.\mathrm{m}^{-2}\right)$} & 60 & 199 & 55 & 51 & 63 & 34 & 54 & 55 & 67 & 60 & 37 & 55 & $108 \pm 13$ & $10 \pm 2$ \\
\hline \multicolumn{2}{|l|}{ Total biomass ( $\mathrm{g} \mathrm{DW} \mathrm{m}^{-2}$ ) } & 158 & 315 & 106 & 122 & 159 & 120 & 121 & 184 & 166 & 148 & 98 & 194 & $207 \pm 24$ & $47 \pm 5$ \\
\hline \multicolumn{2}{|l|}{ Species richness } & 6 & 10 & 9 & 9 & 15 & 13 & 14 & 12 & 13 & 14 & 14 & 17 & $18.2 \pm 0.2$ & $5 \pm 1$ \\
\hline \multicolumn{2}{|l|}{ Patch size $\left(\mathrm{cm}^{2}\right)$} & 5 & 16 & 20 & 44 & 79 & 133 & 143 & 154 & 254 & 269 & 299 & 314 & 40000 & 0 \\
\hline
\end{tabular}

The total biomass of associated macrofauna (excluding Mytilus) in the patches ranged between 98 and $315 \mathrm{~g}$ dry weight (DW) $\mathrm{m}^{-2}$, on average comprising $17.4 \pm 2 \%$ of the total assemblage including Mytilus. The biomass of macrofauna in the control area was smaller $(45 \pm 5 \mathrm{~g} \mathrm{DW}$ $\mathrm{m}^{-2}$ ) than in the patches and mussel bed (Table 1). As for the abundance, the Mollusca (excluding Mytilus) biomass was largest in the patches and bed. In contrast to patches and bed, Macoma balthica had the largest biomass, $27.4 \mathrm{~g} \mathrm{DW} \mathrm{m}^{-2}$, in the control.

\section{Infauna community}

The infauna community at 1 to $10 \mathrm{~cm}$ depth was significantly different between mussel patches and

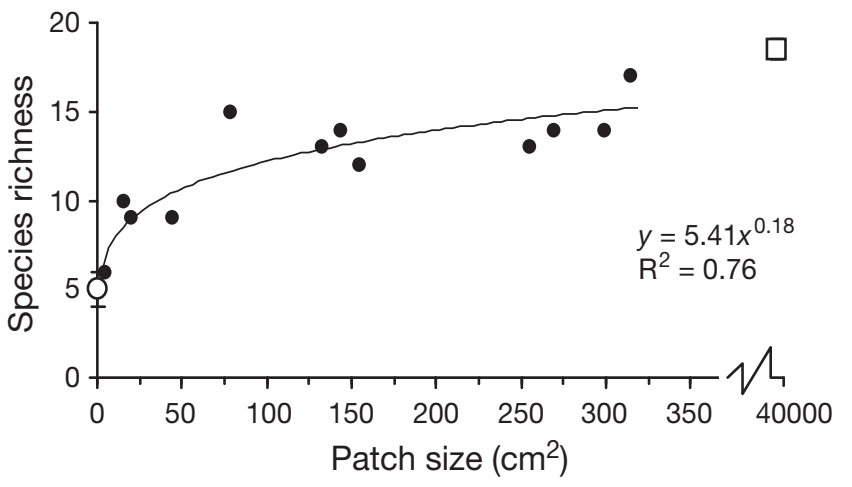

Fig. 2. Macrofauna species richness in Mytilus patches of different size $(\mathrm{N}=12)$, and mean $\pm \mathrm{SE}$ for control area and mussel bed $(\mathrm{n}=5)$; curve fitted only for patches. $\bullet=$ patch samples, $\mathrm{O}=$ control samples, $\square=$ mussel bed samples 
Table 2. Quasi-Newton model estimated fit of correlation between macrofauna species richness and patch area $(\mathrm{n}=12)$

\begin{tabular}{|lcccc|}
\hline Parameter & Estimate & SE & $t$ & $p$ \\
\hline$\alpha$ & 5.41 & 0.99 & 5.47 & $<0.001$ \\
$\beta$ & 0.178 & 0.04 & 4.88 & $<0.001$ \\
\hline
\end{tabular}

bare sediment. The species richness was significantly higher (ANOVA, $F_{1,35}=5.83, \mathrm{p}=0.02$ ) beneath the mussel patches (mean \pm SE $8.0 \pm 0.4$ species) (Fig. 3) compared to the bare sediment with $6.7 \pm 0.3$ species; 2 infauna species only occurred $>1 \mathrm{~cm}$ below the sediment surface, Marenzelleria neglecta and Boccardia cf. ligerica. However, M. neglecta was not present in mussel patches $>1418 \mathrm{~cm}^{2}$. Beneath mussels patches, a weak negative relationship was found between species richness and patch size ( $\left.L R, p=0.028, r^{2}=0.22\right)$. The dominant taxa beneath the patches were Oligochaeta, Hydrobia ulvae, Macoma balthica and Hediste diversicolor. Significantly higher abundances of $H$. diversicolor (ANOVA, $F_{1,35}=10.1, \mathrm{p}=0.003$ ) were found beneath mussel patches compared to bare sediment.

\section{Macroalgae}

No macroalgae were found in the control area on the bare sediment, but when Mytilus was present, several macroalgae species were present (Fig. 4). Species richness did not increase with increasing patch size (NR, $\mathrm{p}=0.34)$.

Six macroalgae species were found, of which Furcellaria lumbricalis dominated in terms of biomass, followed in decreasing order by Pilayella littoralis, Polysiphonia fucoides, Ceramium tenuicorne, Phyllophora pseudoceranoides and Rhodomela confervoides (Fig. 5). F. lumbricalis and Phyllophora pseudoceranoides were found entangled in byssus threads of the mussels. Only C. tenuicorne and Polysiphonia fucoides were attached

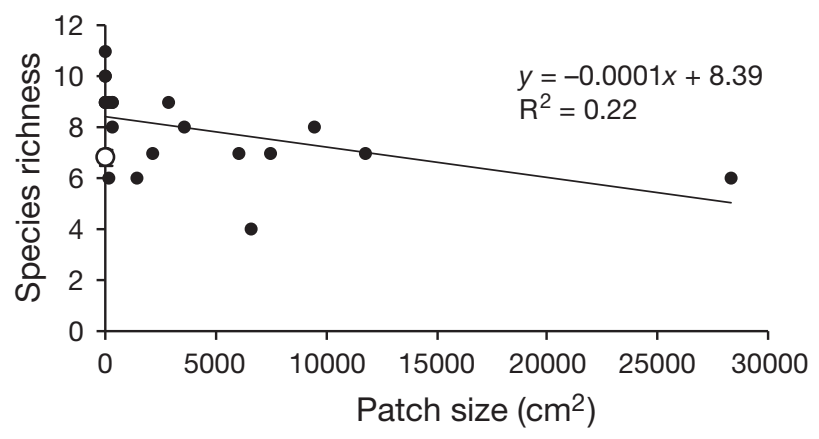

Fig. 3. Macro-infauna species richness beneath Mytilus patches of different size $(n=22)$, and mean \pm SE for the control with bare sediment $(\mathrm{n}=15)$. $\bullet$ = patch samples, $\mathrm{O}=$ control samples

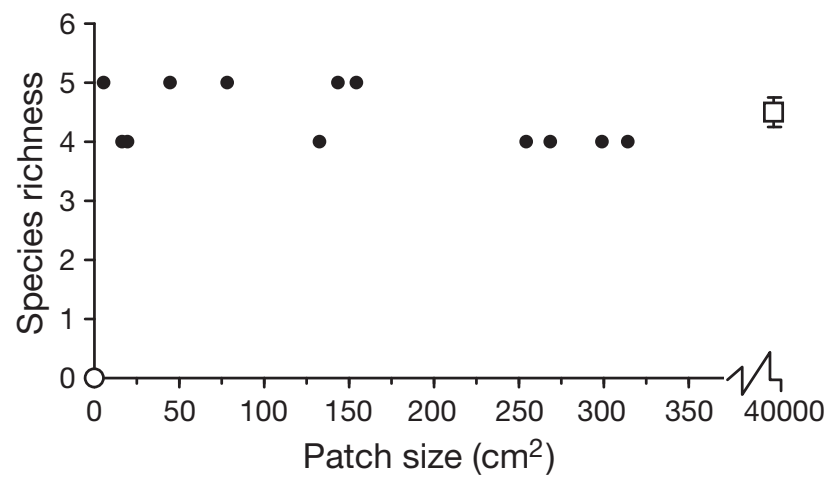

Fig. 4. Macroalgae species richness in Mytilus patches of different size $(n=12)$, and mean \pm SE for control area and mussel bed $(\mathrm{n}=5) \cdot \bullet=$ patch samples, $\mathrm{O}=$ control samples, $\square=$ mussel bed samples

directly to the Mytilus shell, while Pilayella littoralis was represented by loose-lying and drifting algae that had been trapped by the patches.

The total macroalgal biomass was very low (Figs. 5 $\& 6$ ), on average $5.6 \%$ of the total associated fauna and flora. The biomass in patches varied between 2.7 and $14.6 \mathrm{~g} \mathrm{DW} \mathrm{m}^{-2}$ with a mean of $6.7 \mathrm{~g} \mathrm{~m}^{-2}$. In the mussel bed, the biomass was on average $8.6 \mathrm{~g} \mathrm{DW} \mathrm{m}^{-2}$. The biomass of algae did not increase with patch size (Spearman, $t=-0.77, \mathrm{p}=0.46$ ), but the biomass of individual species did. Furcellaria lumbricalis was positively correlated with patch size (Spearman, $t=2.7$, $\mathrm{p}=0.02$ ), while Polysiphonia fucoides was negatively correlated (Spearman, $t=3.3, \mathrm{p}=0.008$ ).

\section{Functional groups}

In Table 1 and Fig. 6 the fauna have been divided into functional groups, depending on feeding type, with additional information on spatial position in the mussel matrix. The sediment control had a total of 5

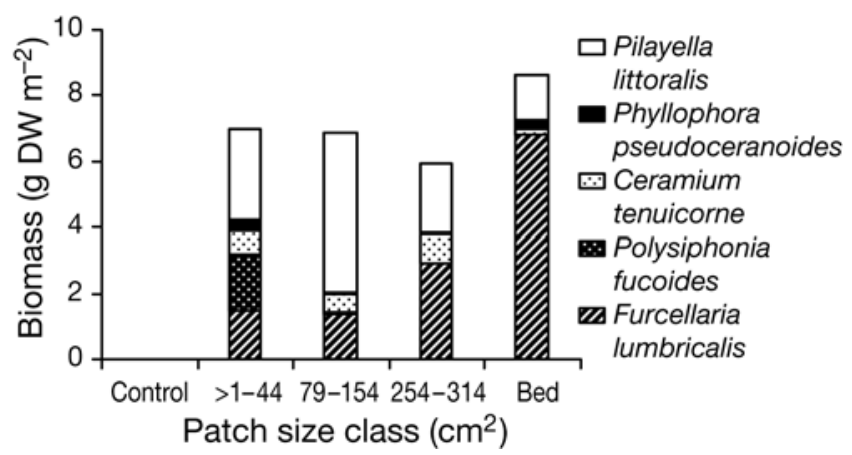

Fig. 5. Mean biomass of macroalgae species in Mytilus patches of different patch size class $(n=4)$, control area $(n=5)$ and mussel bed $(n=5)$ 


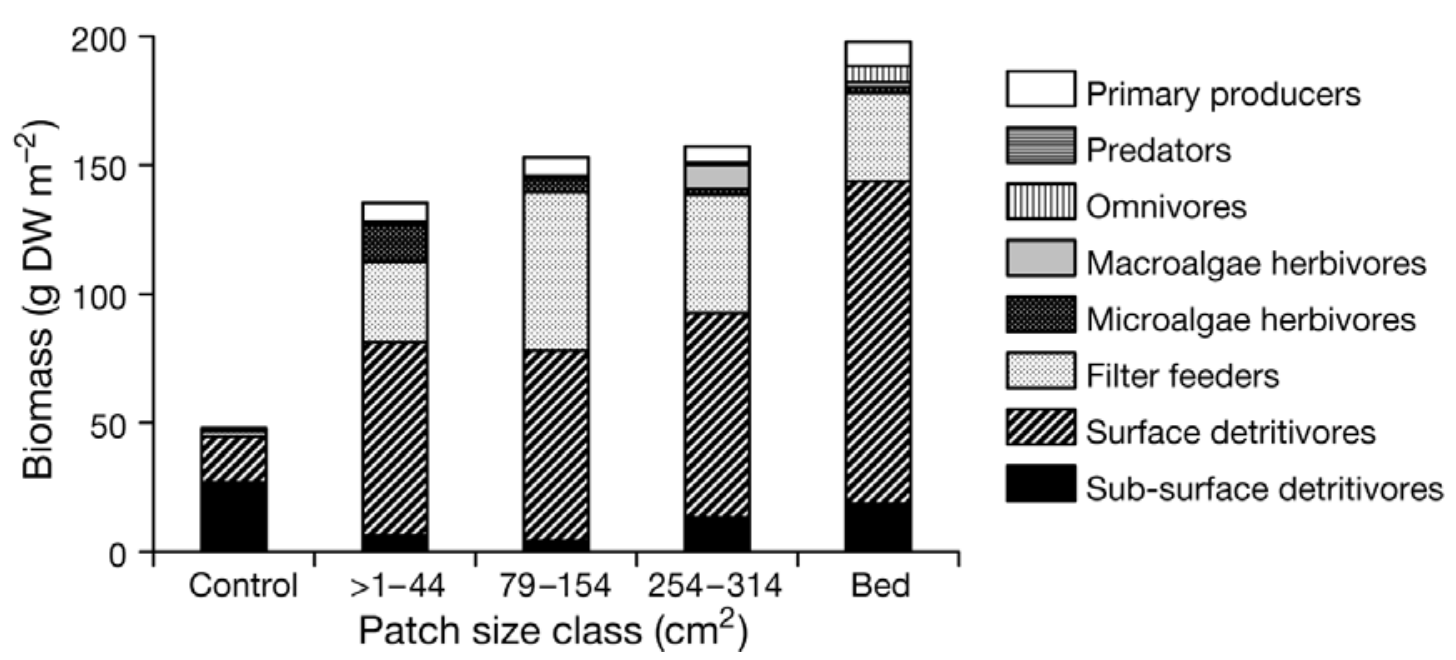

Fig. 6. Mean biomass of functional groups (by feeding mode) in Mytilus patches of different size class $(\mathrm{n}=4)$, control area $(\mathrm{n}=5)$ and mussel bed $(n=5)$

functional groups, while the patches had 8 and the mussel bed had 9 groups. The biomass of surface detritivores (Hydrobia ulvae, Potamopyrgus antepodarum and Pygospio elegans) was significantly different (ANOVA, square root, $F_{4,17}=21.4, \mathrm{p}<0.001$ ) between the control area, patches and mussel bed. It was higher in Mytilus patches (SNK, $\mathrm{n}=4, \mathrm{p}<0.001$ for small, medium and large patches, respectively) and mussel bed (SNK, $\mathrm{n}=5, \mathrm{p}<0.001)$ compared to the control area (Fig. 6), and higher biomass in the mussel bed, compared to the patches (SNK, $\mathrm{n}=4, \mathrm{p}=0.01$ for small, $\mathrm{p}=0.02$ for medium and $\mathrm{p}=0.01$ for large patches, respectively). In contrast, the highest biomass of subsurface detritivores was found in the sediment control area, and was significantly different (ANOVA, square root, $\left.F_{4,17}=5.67, \mathrm{p}=0.004\right)$ from the small (SNK, $\mathrm{n}=4$, $\mathrm{p}=0.01$ ) and medium (SNK, $\mathrm{n}=4, \mathrm{p}=0.007$ ) patch classes.

The filter-feeder biomass (Balanus improvisus, Mya arenaria and Cerastoderma glaucum) was significantly different between control area, patches and mussel bed (ANOVA, $\left.F_{4,17}=12.8, \mathrm{p}<0.001\right)$. The biomass was smaller in the control area compared to the patches (SNK, $\mathrm{n}=4, \mathrm{p}<0.005$ for small, $\mathrm{p}<0.001$ for medium and $\mathrm{p}<0.001$ for large patches, respectively) and the mussel bed (SNK, $\mathrm{n}=5, \mathrm{p}=0.005)$. The microalgae herbivores (Theodoxus fluviatilis and Jaera albifrons) dominated the herbivore biomass in small patches, while macroalgae herbivores (Idothea balthica, I. viridis and Limapontia capitata) dominated in the large patches. In the mussel bed the herbivore biomass was low, but the omnivore biomass, primarily represented by Gammarus sp., was significantly higher (ANOVA, square root, $F_{4,17}=31.4, \mathrm{p}<0.001$ ) than in all patch classes (SNK, $\mathrm{n}=4, \mathrm{p}<0.001$ for all classes) and the control (SNK, $\mathrm{n}=5, \mathrm{p}<0.001)$.

\section{Meiofauna}

A total of 21 meiofauna taxa were found in the Mytilus patches, representing 8 phyla (Table 3). The average number of meiofauna taxa was not different (ANOVA, $F_{2,33}=1.0, \mathrm{p}=0.37$ ) between the Mytilus patches compared to $30 \mathrm{~cm}$ outside the patches and the control area (Table 3). On average, $16.9 \pm 0.6$ taxa were found in the patches, $16.6 \pm 0.6$ outside patches, $15.7 \pm 0.6$ in the sediment control and $16 \pm 0.6$ taxa in the mussel bed. The number of meiofauna taxa showed a weak positive relationship with increasing patch size $\left(\mathrm{NR}, \mathrm{p}=0.02, \mathrm{r}^{2}=0.48\right)$, as the smallest patches had 13 taxa and the larger patches reached a maximum of 19 taxa.

The abundance of meiofauna was significantly different (ANOVA, $F_{2,33}=5.7, p=0.008$ ) between the control, outside and inside the patches. The abundance was significantly higher inside (SNK, $\mathrm{n}=12, \mathrm{p}=$ 0.006) and outside (SNK, $\mathrm{n}=12, \mathrm{p}=0.04$ ) the Mytilus patches compared to the control area (Table 3). In the mussel bed $(n=5)$, the abundance was similar to that of the larger patches. The meiofauna community inside the patches was dominated by Nematoda, Copepoda and Bivalvia.

The differences in total abundance were mainly due to the dominant Nematoda, followed by Copepoda and Oligochaeta. The Nematoda constituted from about 44 to $81 \%$ (average $66 \%$ ) of the total meiofauna community in Mytilus patches and $70 \%$ in the mussel bed. The nematode abundance was significantly different between control, outside and inside the mussel patches (ANOVA, $F_{2,33}=6.2, \mathrm{p}=0.005$ ). The abundance was significantly higher inside patches compared to outside $(\mathrm{SNK}, \mathrm{n}=12, \mathrm{p}=0.023)$ and control $(\mathrm{SNK}, \mathrm{n}=12$, $\mathrm{p}=0.005$ ) (Table 3 ). The abundance of Copepoda, tem- 
Table 3. Meiofauna abundances $\left(10^{3}\right.$ ind. $\mathrm{m}^{-2}$; mean $\left.\pm \mathrm{SE}\right)$ in Mytilus patches, sediment $30 \mathrm{~cm}$ outside patches and sediment control ( $3 \mathrm{~m}$ from patches) $(\mathrm{n}=12) . F=$ ANOVA statistic. $\mathrm{p}$-values were significant when $\leq 0.05$. nd $=$ taxon not detected, na $=$ not analysed due to too low abundance

\begin{tabular}{|c|c|c|c|c|c|}
\hline & Control & Outside patch & Patch & $F$ & $\mathrm{p}$ \\
\hline Ciliata & $11 \pm 1.8$ & $16 \pm 2.2$ & $15 \pm 2.3$ & 1.5 & 0.25 \\
\hline Foraminifera & $0.5 \pm 0.2$ & $0.8 \pm 0.4$ & $0.8 \pm 0.5$ & 0.2 & 0.82 \\
\hline Rotifera & $2.0 \pm 0.5$ & $1.9 \pm 0.6$ & $0.6 \pm 0.4$ & 2.3 & 0.12 \\
\hline \multicolumn{6}{|l|}{ Kinorhyncha } \\
\hline Echinoderes levanderi & nd & $0.2 \pm 0.2$ & $0.2 \pm 0.2$ & 0.5 & 0.61 \\
\hline \multicolumn{6}{|l|}{ Hydrozoa } \\
\hline Protohydra leuckarti & $6.0 \pm 1.3$ & $11 \pm 1.9$ & $5.8 \pm 1.7$ & 3.2 & 0.05 \\
\hline Platyhelmintes & $19 \pm 4.0$ & $24 \pm 1.8$ & $21 \pm 3.3$ & 1.2 & 0.31 \\
\hline Nematoda & $230 \pm 30$ & $285 \pm 27$ & $411 \pm 51$ & 6.2 & $<0.01$ \\
\hline Polychaeta (total) & $4.6 \pm 0.9$ & $9.1 \pm 1.7$ & $11 \pm 3.0$ & 1.7 & 0.19 \\
\hline Manayunkia aestuarina & $3.0 \pm 0.9$ & $6.4 \pm 1.5$ & $7.5 \pm 2.7$ & 0.6 & 0.54 \\
\hline Spionidae & $1 \pm 0.4$ & $1 \pm 0.6$ & $1 \pm 0.5$ & 0.1 & 0.88 \\
\hline Nereis diversicolor & $0.2 \pm 0.2$ & $0.3 \pm 0.2$ & $1 \pm 0.5$ & na & na \\
\hline Other & nd & $0.9 \pm 0.8$ & $0.8 \pm 0.3$ & 1.1 & 0.35 \\
\hline Oligochaeta & $55 \pm 6.1$ & $59 \pm 6.5$ & $40 \pm 6.0$ & 2.6 & 0.09 \\
\hline Copepoda (total) & $37 \pm 4.8$ & $85 \pm 7.5$ & $84 \pm 20$ & 8.6 & $<0.001$ \\
\hline Harpacticoida & $31 \pm 1.6$ & $62 \pm 6.3$ & $37 \pm 5.6$ & 9.4 & $<0.001$ \\
\hline Cyclopoida & $1.3 \pm 0.4$ & $0.9 \pm 0.4$ & $23 \pm 10$ & 4.8 & $<0.05$ \\
\hline Copepodita & $3.0 \pm 0.6$ & $7.1 \pm 1.3$ & $10 \pm 2.6$ & 3.1 & 0.06 \\
\hline Nauplia & $3.9 \pm 0.9$ & $15 \pm 4.1$ & $14 \pm 3.6$ & 6.3 & $<0.01$ \\
\hline Ostracoda & $7.2 \pm 1.3$ & $10 \pm 1.3$ & $6.4 \pm 1.2$ & 2.7 & 0.09 \\
\hline Acarida: Halacaridae & $5.5 \pm 2.3$ & $15 \pm 3.9$ & $7.1 \pm 1.5$ & 3.6 & $<0.05$ \\
\hline Gastropoda (total) & $17 \pm 3.1$ & $22 \pm 3.9$ & $12 \pm 2.1$ & 2.6 & 0.09 \\
\hline Hydrobia sp. & $12 \pm 2.7$ & $18 \pm 3.9$ & $11 \pm 2.2$ & 1.8 & 0.19 \\
\hline Limapontia capitata & $4.7 \pm 1.0$ & $3.5 \pm 0.9$ & $1.1 \pm 0.5$ & 4.8 & $<0.05$ \\
\hline Bivalvia (total) & $0.5 \pm 0.2$ & $3.8 \pm 0.7$ & $3.3 \pm 0.9$ & 8.2 & $<0.01$ \\
\hline Macoma balthica & $0.5 \pm 0.2$ & $3.6 \pm 0.7$ & $3.0 \pm 0.9$ & 7.8 & $<0.01$ \\
\hline Cerastoderma sp. & nd & $0.2 \pm 0.2$ & $0.3 \pm 0.2$ & na & na \\
\hline Insecta: Chironomidae & $0.6 \pm 0.3$ & $0.2 \pm 0.2$ & $1.9 \pm 0.5$ & 6.5 & $<0.01$ \\
\hline Mean total abundance & $395 \pm 38$ & $547 \pm 27$ & $619 \pm 68$ & 5.7 & $<0.01$ \\
\hline Mean number of taxa & $15.7 \pm 0.6$ & $16.6 \pm 0.6$ & $16.9 \pm 0.6$ & 1.0 & 0.37 \\
\hline
\end{tabular}

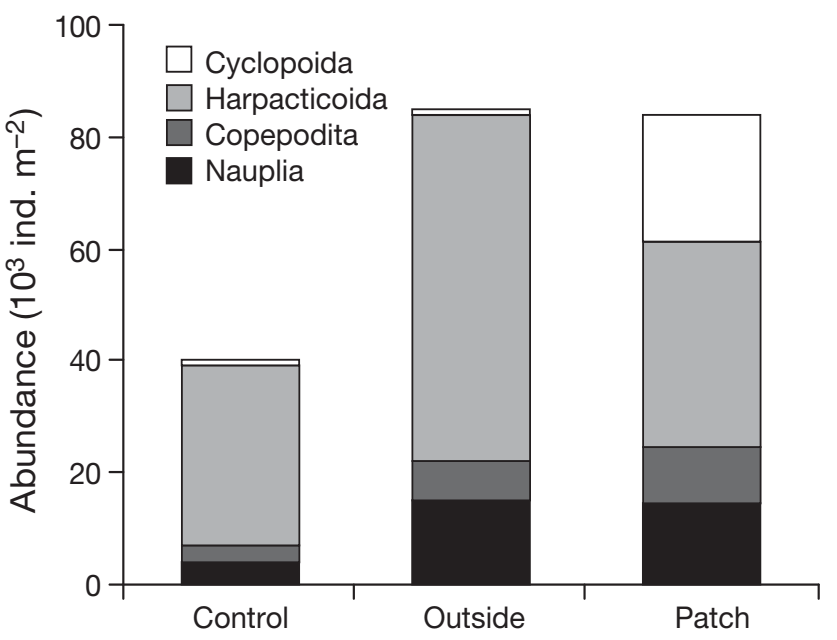

Fig. 7. Mean abundance of Copepoda at different sampling areas $(\mathrm{n}=12)$. Abundance was significantly higher inside and outside Mytilus patches, compared to control area; abundance of Cyclopoida was significantly higher in patches than outside and control poral Bivalvia meiofauna (excluding Mytilus), nauplii and Chironomidae were significantly higher inside and outside Mytilus patches compared to the control (Table 3), whereas Turbellaria and Oligochaeta were equally abundant at all spatial scales.

For the composition of Copepoda, the relative abundances of Harpacticoida and Cyclopoida were significantly different (ANOVA, square root, $F_{2,33}=4.8, \mathrm{p}=0.035$ and $F_{2,33}=$ $9.5, \mathrm{p}<0.001$ respectively) between control, inside and outside patches (Table 3). The Cyclopoida abundance was much higher inside, compared to outside and in the control area (SNK, $\mathrm{n}=12, \mathrm{p}=0.035)$ (Fig. 7). The Nauplia abundance was also significantly different between the 3 sampling positions $\left(\right.$ ANOVA, 4 th root, $F_{2,33}=6.3, \mathrm{p}<$ 0.01 ), with lower abundance in the control, compared to outside and inside patches ( $\mathrm{SNK}, \mathrm{n}=12, \mathrm{p}=0.006$ and $\mathrm{p}=0.004$, respectively).

The abundance of meiofauna increased with increasing patch size at smaller patch sizes, but levelled off at larger sizes and at mussel bed size. A positive relationship between abundance and LOI was found ( $L R, p<0.001, r^{2}=0.52$ ) for the patch samples (including control, inside and outside patches), but at the bed scale no relationship was found. The relationship between abundance (Fig. 8) and LOI (Fig. 9) with patch size showed similar patterns for patches, but were different for the mussel bed.

\section{Sediment}

There was a sharp contrast in organic content of the surface sediment (0 to $2 \mathrm{~cm}$ ) outside, compared to inside Mytilus patches. The content in terms of LOI was significantly different (ANOVA, 4th root, $\left.F_{2,33}=31.5, \mathrm{p}<0.001\right)$ between the sediment control area, outside and inside patches. The content was higher inside the patches than $30 \mathrm{~cm}$ outside (SNK, $\mathrm{n}=12, \mathrm{p}<0.001$ ) and at the control area (SNK, $\mathrm{n}=12, \mathrm{p}<0.001$ ), but the content in the patches was less than half of that recorded in the mussel bed (Table 4, Fig. 9). 


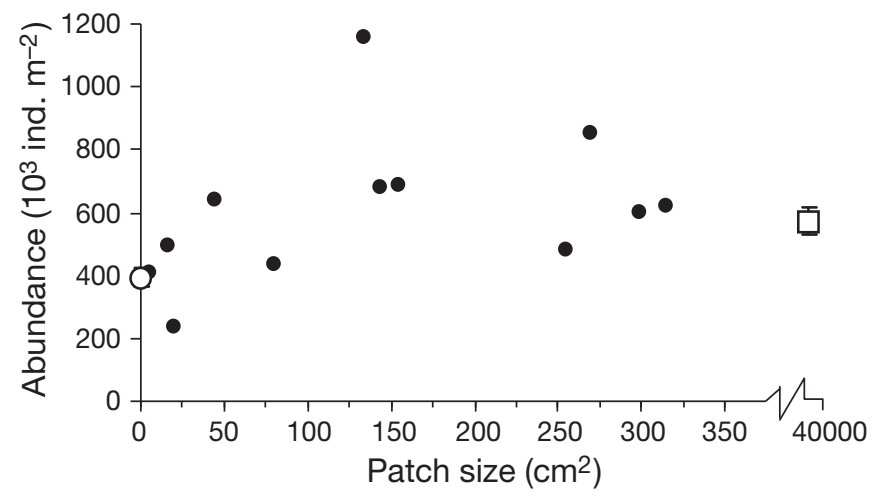

Fig. 8. Abundance of meiofauna in Mytilus patches of different size $(n=12)$, and average meiofauna abundance $( \pm$ SE) for control area $(n=5)$ and mussel bed $(n=5) . \bullet=$ patch samples, $\mathrm{O}=$ control samples, $\square=$ mussel bed samples

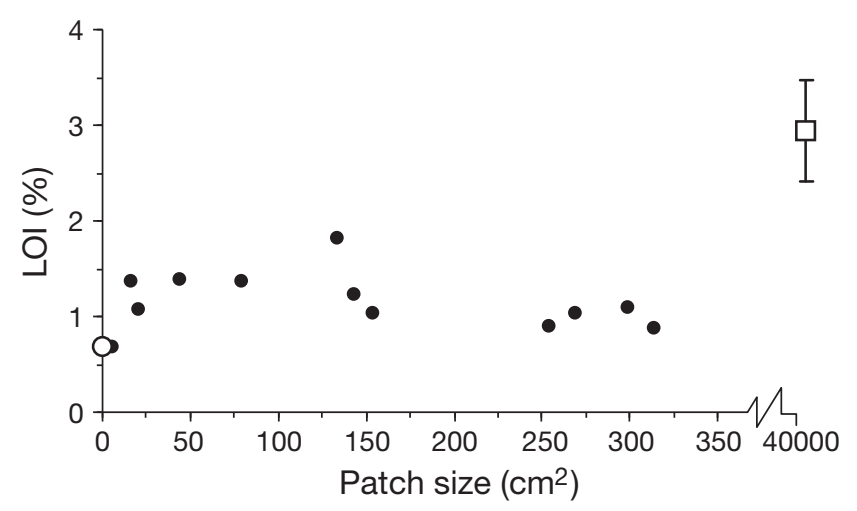

Fig. 9. Loss on ignition (LOI) in sediment of Mytilus patches of different size $(\mathrm{n}=12)$, and average \pm SE for control area $(\mathrm{n}=$ 5) and mussel bed $(n=5)$. $\bullet=$ patch samples, $\mathrm{O}=$ control samples, $\square=$ mussel bed samples

Total organic carbon and nitrogen contents in sediment followed the same pattern as LOI (Table 4). The sediment control had low contents of carbon and nitrogen. The contents almost doubled in the Mytilus patches, but were only $40 \%$ of that found in the mussel bed. The water content of the sediment was higher inside the patches compared to outside and varied between 20 and $40 \%$ (Table 4), indicating a change of texture in the sediment. The recorded differences are probably underestimated as the top $2 \mathrm{~cm}$ of the sediment was homogenised and analysed, which means that the water, nutrient and organic content of any top layer thinner than $2 \mathrm{~cm}$ may have been 'diluted' by the underlying sand.

The mussel bed had on average about 3 times higher content of carbon compared to the patches, and 50\% higher water content. The bed data also showed the highest variation between samples. The $\mathrm{C}: \mathrm{N}$ ratios of the sediment were on average $7.8 \pm 0.1$ in the control area, $7.9 \pm 0.1$ in Mytilus patches and $8.0 \pm 0.2$ in the mussel bed, but were not significantly different.

\section{DISCUSSION}

The presence of Mytilus was very important for biodiversity, as a total of 50 taxa of associated macro- and meiofauna and macroalgae were found on a sublittoral sediment bottom. Even very small mussel patches had a large impact on the associated fauna and the number of macrofauna species increased to 6 to 18.5 species as soon as Mytilus was present, compared to an average of only 5 species in the surface layer of the bare sediment control. Also the macro-infauna community deeper in the sediment beneath the mussel patches had significantly higher species richness, compared to sediment without patches. In total, 24 macrofauna species were found in all samples associated to mussels while only 10 species were associated to bare sediment. Macroalgae, sessile fauna (Balanus improvisus, Electra pilosa) and grazers (Lymnea peregra, Limapontia capitata) were only found within the mussel patches.

The species richness of associated species in mussel patches is similar to that of other highly diverse habitats in the Baltic Sea. The average of 18.5 and total of 24 macrofauna species and 19 meiofauna taxa found in the Mytilus patches on sediment bottoms at $7 \mathrm{~m}$ depth

Table 4. Sediment characteristics (mean $\pm \mathrm{SE}$ ): water content, loss on ignition (LOI), carbon, nitrogen and C:N ratio in Mytilus patch samples, mussel bed, control area and $30 \mathrm{~cm}$ outside patches

\begin{tabular}{|lrlllll|}
\hline & $\mathrm{n}$ & Water $(\%)$ & LOI $(\%)$ & $\mathrm{C}(\%)$ & N $(\%)$ & C:N \\
\hline Control & 12 & $29.2 \pm 1.4$ & $0.69 \pm 0.03$ & $0.24 \pm 0.01$ & $0.03 \pm 0.001$ & $7.8 \pm 0.1$ \\
Outside & 12 & $28.3 \pm 1.0$ & $0.68 \pm 0.01$ & $0.24 \pm 0.01$ & $0.03 \pm 0.002$ & $7.8 \pm 0.1$ \\
Patch (mean) & 12 & $33.3 \pm 1.7$ & $1.16 \pm 0.1$ & $0.45 \pm 0.1$ & $0.06 \pm 0.01$ & $7.9 \pm 0.1$ \\
Small (>1-44) & 4 & $32.3 \pm 4.0$ & $1.13 \pm 0.2$ & $0.40 \pm 0.1$ & $0.05 \pm 0.01$ & $8.0 \pm 0.2$ \\
Medium (79-154) & 4 & $36.6 \pm 2.2$ & $1.37 \pm 0.2$ & $0.55 \pm 0.1$ & $0.07 \pm 0.1$ & $8.0 \pm 0.2$ \\
Large (254-314) & 4 & $30.9 \pm 2.6$ & $0.98 \pm 0.06$ & $0.39 \pm 0.03$ & $0.05 \pm 0.003$ & $7.7 \pm 0.2$ \\
Mussel bed & 5 & $50.2 \pm 2.5$ & $2.94 \pm 0.5$ & $1.28 \pm 0.2$ & $0.16 \pm 0.02$ & $8.0 \pm 0.2$ \\
\hline
\end{tabular}


was similar to that of the Mytilus-red algal belt on a nearby rocky bottom at the same depth (Kautsky 1974). The same total number of macrofauna species were also found in the Mytilus-red algae community on hard substratum at $5 \mathrm{~m}$ depth at the island of Öland, northern Baltic proper (P. Norling et al. unpubl.). In the Fucus vesiculosus belt, which is generally considered to be the most species-rich habitat in the Baltic, Haage \& Jansson (1970) found on average 18.5 and a total of 26 associated macrofauna species at $2 \mathrm{~m}$ depth in the Askö Archipelago, and Råberg (2004) found a total of 24 species at $0.4 \mathrm{~m}$ depth in the same area. In comparison with Ankar \& Elmgren (1976), who found on average only 8 macrofauna species on sediment bottoms in the Askö area at 9 to $50 \mathrm{~m}$ depth, the frequently occurring Mytilus patches on these bottoms are thus 'islands of high biodiversity'.

Both structural and functional traits of Mytilus influenced species richness, composition and abundance of macroalgae, macro-infauna, and macro- and meiofauna in the mussel patches. The secondary substratum provided by mussel shells proved to be very important for some macrofauna as well as for attachment of macroalgae (cf. Albrecht 1998, Buschbaum 2000). Polychaeta and Nemertinea were more frequent in the larger patches, probably due to the presence of large Mytilus individuals providing more complex structure and sheltering cavities between mussels and shells (Gutiérrez et al. 2003).

Patch size affected species richness of macrofauna, but not meiofauna. The different response patterns suggest that meiofauna is more related to functional traits of Mytilus, such as biodeposition. Species richness of macrofauna increased with Mytilus patch area, as shown in more marine areas for patches on hard substratum (Tsuchiya \& Nishihira 1985), as well as sediment bottoms (Norling \& Kautsky 2007). The low salinity and fewer species in the Baltic Sea resulted in a macrofauna diversity that was approximately half of the numbers found in intertidal sediment mussel beds (Dittmann 1990), shallow patches (Norling \& Kautsky 2007) and large subtidal patches (Svane \& Setyobudiandi 1996) in more marine areas. However, the dominant taxonomic groups of macrofauna were different in the present study, compared to more marine areas. Gastropoda (Hydrobia ulvae) and Bivalvia (Cerastoderma glaucum) dominated, followed by Crustacea (having most species), while mussel patches in more marine intertidal habitats are generally dominated by Polychaeta and Crustacea, followed by Mollusca (see reviews: Seed 1996, Thiel \& Ullrich 2002, Chintiroglou et al. 2004).

In the present study, the Polychaeta Hediste diversicolor, which has several feeding modes (predator, grazer and filter feeder using mucus net) (Fauchald
\& Jumars 1979), was found in almost all samples. This dominance is probably a result of the low species diversity in the Baltic Sea, which allows organisms to have wider realised niches than normally found in fully marine areas (Remane \& Schlieper 1971). In addition, the facilitation by Mytilus has the potential of further increasing the realised niche for associated species (Bruno et al. 2003).

Another reason for the differences in dominant species composition, compared to more marine environments, is probably that most studies were carried out in the intertidal zone, while the present study was conducted at $7 \mathrm{~m}$ depth in an area where effects of waves are small and tidal exposure is non-existent. In a comparative study of tidal zones, Saier (2002) found higher average species richness in the subtidal $(1 \mathrm{~m}$ at mean low tide) than in the intertidal zone, while the total abundance was higher in the intertidal mussel bed. In comparison, the present study, with more stable conditions due to larger depths, showed approximately the same species richness as in the subtidal zone, and even higher abundance. This is probably due to increasing sedimentation of organic rich matter and less wave action, making more food available. The stable habitat makes species composition very distinctive with deposit- and filter-feeder domination, and this favours bivalves like Cerastoderma glaucum in surface-feeding. The inhibition of macro-infauna beneath mussel beds that is seen in many intertidal studies (Dittmann 1990, Commito \& Dankers 2001) was not found here. Although biodeposition is high, only a weak inhibition effect was noted with increasing patch size, probably because the mussel matrix was not dense and complex enough to trap large amounts of sediment with high organic matter.

Macroalgae were totally dependent on the presence of Mytilus, as no algae were found outside patches and the algae biomass increased with patch size, especially of the perennial red algae Furcellaria lumbricalis. Single mussels provided substrate for several macroalgae species such as Ceramium tenuicorne and Polysiphonia fucoides, while F. lumbricalis and Phyllophora pseudoceranoides that are to a large extent vegetatively propagated in the Baltic Sea (Kautsky \& Wallentinus 1980) were usually found entangled and attached by the byssus threads of mussels. This close association between mussels and algae, which cooccur down to a depth of more than $20 \mathrm{~m}$ in the Baltic Sea, is likely further enhanced by the ability of Mytilus to clear the water and regenerate nutrients which may be of great importance for the algae (Kautsky \& Wallentinus 1980). The presence of macroalgae in mussel patches is in turn an important secondary factor in determining the community structure of the fauna (Arrontes 1999, Buschbaum 2000). Thus, in large 
patches with denser F. lumbricalis cover, Amphipoda and Isopoda became much more frequent together with the algae-feeding nudibranch.

In addition to the positive species-richness effect, the number of functional groups increased when mussels were present. Compared to the sediment control, where 5 functional groups were found, with dominance of the subsurface detritivore Macoma balthica and surface detritivore Hydrobia ulvae, additional filter feeders, herbivores and primary producers were found in Mytilus patches, which had a total of 8 functional groups. In the patches, the biomass of herbivores increased with increasing patch size, with microalgae herbivores having high abundance in the small patches but being replaced by macroalgae herbivores and omnivores in the largest patches and the mussel bed. Thus the largest increase with patch size was observed in algae grazers such as amphipods and isopods that feed or seek shelter in the increasing amount of algae.

While the number of meiofauna taxa was not different in Mytilus patches, compared to $30 \mathrm{~cm}$ outside the patches or in the control area $3 \mathrm{~m}$ away, the abundance was significantly higher within and outside patches than in the control area. The difference was mainly due to a domination of nematodes inside the mussel patches and bed, which corresponds well with Radziejewska (1986), who showed that nematodes dominated the meiobenthos in Baltic subtidal sediments and had higher densities in the immediate neighbourhood of mussel patches. The Copepoda abundance in the present study was also higher inside the patches, and a shift was observed in the copepod community, where larger Cyclopoida totally dominated in patches at the cost of smaller Harpacticoida, which were more abundant outside the patches.

The higher meiofauna abundance inside patches could be related to the organic content of the sediment up to a patch size of $314 \mathrm{~cm}^{2}$. However, at the mussel bed scale, with organic content twice as high as in the largest patches, no relationship was found. This may be explained by the organic content having exceeded the optimal level for the meiofauna beyond which e.g. the oxygen level goes down, indicated by a smell of hydrogen sulphide in sediment cores from the mussel bed. The large differences in organic content between patches and bed may be due to differences in hydrodynamic conditions around patches compared to a mature bed, and to the age of patches. While all patches were probably $>5$ yr old, based on observed population size structure (cf. Kautsky 1982), the bed was substantially older, resting on a thicker layer of dead shells and old biodeposits.

Even the smallest Mytilus patches profoundly changed the surface sediment characteristics and had signifi- cantly higher organic content, compared to outside the patches and the control area. Annual biodeposition within a $100 \mathrm{~cm}^{2}$ patch generated by mussels with an average biomass of $9.26 \mathrm{~g}$ DW including shells (as observed in the present study) would be about $3.1 \mathrm{~g} \mathrm{DW}$, $1.2 \mathrm{~g}$ carbon, $0.16 \mathrm{~g}$ nitrogen and $0.02 \mathrm{~g}$ phosphorus, which is much higher than the natural sedimentation over the same area, but less than in a more marine mussel bed (recalculated from Kautsky \& Evans 1987). As shown in the present study, only part of this is, however, accumulated within the patch, leading to enriched sediment, while the rest is consumed by the associated fauna, degraded by micro-organisms, or re-suspended and exported to surrounding areas. The observed increase in abundance of fauna and biomass of macroalgae with patch size is partly due to structure, but also due to the mussels supplying functional resources that increase carrying capacity and biomass, in accordance with a study on the Swedish west coast where the associated community was supplied with 24 to $31 \%$ of its energy demand by the mussels (Norling \& Kautsky 2007).

In contrast to our results, which show predominantly positive effects of organic enrichment, studies from more marine areas usually show significantly lower abundances of meiofauna and macroscopic infauna within mussel patches, compared to outside, due to high accumulation of organic matter and oxygen depletion (Dittmann 1990, Commito \& Dankers 2001). This difference is probably due to the fact that low salinities in the Baltic Sea lead to smaller size, weaker byssus threads and lower physiological activity of mussels (Tedengren \& Kautsky 1986), which results in thinner and more loosely connected mussel bed matrices and lower biodeposition per area, compared to the more marine mussel beds that have large highly active mussels which form complex matrices and are thereby likely to trap more sediment.

The present study showed that several abiotic and biotic factors change with patch size, due to structural as well as functional traits of Mytilus and that this had large effects on the associated fauna and flora. Above the sediment surface, facilitating effects by the mussels increased with increasing patch size and showed that this predominately small-patch habitat has a large effect on biodiversity. The low level is probably due to the low species diversity of the Baltic Sea. In the sediment beneath the patches, the inhibiting effects were not as clear as we had hypothesised and at the mussel bed scale it was only pronounced for the meiofauna abundance. Opposite to what was expected, the species richness of macro-infauna was higher beneath patches, compared to the bare sediment.

We conclude that the presence of Mytilus may be as important for species diversity in the Baltic Sea as the 
Fucus vesiculosus community, by having an almost as high number of associated species. Mytilus has an even wider distribution and, most importantly, the capacity of transforming a species-poor soft bottom into a high-diversity environment. Even very small patches will increase abundance and biodiversity (species richness) of associated fauna and flora, which will have implications when studying spatial biodiversity patterns in sediment communities. Furthermore, the mussels make it possible for algae to colonise this sediment habitat, which in turn attracts and supports even more species. Both the structural and functional effects of Mytilus are important for biodiversity. With increasing patch size, the functional effects become more pronounced, but in comparison to more marine areas, the inhibiting effects of biodeposition are weak.

Acknowledgements. We thank S. Qvarfordt, K. Norling and A. Wallin for field assistance, the staff at Askö Laboratory for their helpfulness, and are grateful for valuable comments from S. Wikström, R. Elmgren, A. Norkko and C. Bradshaw that improved earlier drafts. Funding for this project was provided by the Swedish Environmental Protection Agency through the MARBIPP program, Stockholm Marine Research Center (SMF), Royal Swedish Academy of Sciences (KVA), H. Ax:son Johnsons and E \& B Swartz Foundation.

\section{LITERATURE CITED}

Albrecht AS (1998) Soft bottom versus hard rock: community ecology of macroalgae on intertidal mussel beds in the Wadden Sea. J Exp Mar Biol Ecol 229:85-109

Ankar S, Elmgren R (1976) The benthic macro- and meiofauna of the Askö-Landsort area. Contrib Askö Lab Univ Stockholm 11:1-115

Arrontes J (1999) On the evolution of interactions between marine mesoherbivores and algae. Bot Mar 42:137-155

Beadman HA, Kaiser MJ, Galanidi M, Shucksmith R, Willows RI (2004) Changes in species richness with stocking density of marine bivalves. J Appl Ecol 41:464-475

Bruno JF, Bertness MD (2001) Habitat modification and facilitation in benthic marine communities. In: Bertness MD, Gaines SD, Hay ME (eds) Marine community ecology. Sinauer Associates, Sunderland, MA, p 201-218

Bruno JF, Stachowicz JJ, Bertness MD (2003) Inclusion of facilitation into ecological theory. Trends Ecol Evol 18: $119-125$

Buschbaum C (2000) Direct and indirect effects of Littorina littorea (L.) on barnacles growing on mussel beds in the Wadden Sea. Hydrobiologia 440:119-128

Chintiroglou CC, Damianidis P, Antoniadou C, Lantzouni M, Vafidis D (2004) Macrofauna biodiversity of mussel bed assemblages in Thermaikos Gulf (northern Aegean Sea). Helgol Mar Res 58:62-70

- Commito JA (1987) Adult-larval interactions: predictions, mussels and cocoons. Estuar Coast Shelf Sci 25:599-606

Commito JA, Dankers N (2001) Dynamics of spatial and temporal complexity in European and North American soft bottom mussel beds. In: Reise K (ed) Ecological comparisons of sedimentary shores. Springer-Verlag, Heidelberg, p 39-59
Crooks JA (1998) Habitat alteration and community-level effects of an exotic mussel, Musculista senhousia. Mar Ecol Prog Ser 162:137-152

Dayton PK (1972) Towards an understanding of community resilience and the potential effects of enrichments to the benthos at McMurdo Sound, Antarctica. Proc Colloq Conserv Probl Antarct:81-96

Dittmann S (1990) Mussel beds - amensalism or amelioration for intertidal fauna? Helgol Mar Res 44:335-352

Dybern BI, Ackefors H, Elmgren R (1976) Recommendations on methods for marine biological studies in the Baltic Sea. Baltic Mar Biol Publ 1:51-63

Fauchald K, Jumars P (1979) The diet of worms: a study of polychaete feeding guilds. Oceanogr Mar Biol Annu Rev 17:193-284

Gutiérrez JL, Jones CG, Strayer DL, Iribarne OO (2003) Mollusks as ecosystem engineers: the role of shell production in aquatic habitats. Oikos 101:79-90

Haage P, Jansson BO (1970) Quantitative investigations of the Baltic Fucus belt macrofauna. Ophelia 8:187-195

Hacker SD, Gaines SD (1997) Some implications of direct positive interactions for community species diversity. Ecology 78:1990-2003

Jones CG, Lawton JH, Shachak M (1994) Organisms as ecosystem engineers. Oikos 69:373-386

Kautsky N (1974) Quantitative investigation of the red algal belt in the Askö area, northern Baltic proper. Contrib Askö Lab Univ Stockholm 3:1-29

- Kautsky N (1982) Growth and size structure in a Baltic Mytilus edulis population. Mar Biol 68:117-133

- Kautsky N, Evans S (1987) Role of biodeposition by Mytilus edulis in the circulation of matter and nutrients in a Baltic coastal ecosystem. Mar Ecol Prog Ser 38:201-212

Kautsky N, Wallentinus I (1980) Nutrient release from a Baltic Mytilus-red algal community and its role in benthic and pelagic productivity. Ophelia 1:17-30

Kautsky N, Johannesson K, Tedengren M (1990) Genotypic and phenotypic differences between Baltic and North Sea populations of Mytilus edulis evaluated through reciprocal transplantations. 1. Growth and morphology. Mar Ecol Prog Ser 59:203-210

Kautsky U, Kautsky H (1995) Coastal production in the Baltic Sea. In: Eleftheriou A, Ansell D, Smith CJ (eds) The biology and ecology of shallow coastal waters. Olsen \& Olsen, Fredensborg, p 31-38

> Kijewski TK, Zbawicka M, Väinölä R, Wenne R (2006) Introgression and mitochondrial DNA heteroplasmy in the Baltic populations of mussels Mytilus trossulus and $M$. edulis. Mar Biol 149:1371-1385

Norkko A, Hewitt JE, Thrush SF, Funnell GA (2001) Benthicpelagic coupling and suspension-feeding bivalves: linking site-specific sediment flux and biodeposition to benthic community structure. Limnol Oceanogr 46:2067-2072

Norling P, Kautsky N (2007) Structural and functional effects of Mytilus edulis on diversity of associated species and ecosystem functioning. Mar Ecol Prog Ser 351: 163-175

Peake AJ, Quinn GP (1993) Temporal variation in speciesarea curves for invertebrates in clumps of an intertidal mussel. Ecography 16:269-277

Quinn GP, Keough MJ (2002) Experimental design and data analysis for biologists. Cambridge University Press, Cambridge

Råberg S (2004) Competition from filamentous algae on Fucus vesiculosus - negative effects and the implications on biodiversity of associated flora and fauna. Licentiate Phil thesis, Stockholm University 
Radziejewska T (1986) On the role of Mytilus edulis aggregations in enhancing meiofauna communities off the southern Baltic coast. Ophelia 4:211-218

Ragnarsson SA, Raffaelli D (1999) Effects of the mussel Mytilus edulis L. on the invertebrate fauna of sediments. J Exp Mar Biol Ecol 241:31-43

Remane A, Schlieper C (1971) Biology of brackish water. John Wiley \& Sons, New York

Saier B (2002) Subtidal and intertidal mussel beds (Mytilus edulis L.) in the Wadden Sea: diversity differences of associated epifauna. Helgol Mar Res 56:44-50

Seed R (1996) Patterns of biodiversity in the macro-invertebrate fauna associated with mussel patches on rocky shores. J Mar Biol Assoc UK 76:203-210

Svane I, Setyobudiandi I (1996) Diversity of associated fauna in beds of the blue mussel Mytilus edulis L.: effects of location, patch size, and position within a patch. Ophelia 45:39-53

Tedengren M, Kautsky N (1986) Comparative study of the physiology and its probable effect on size in blue mussels (Mytilus edulis L.) from the North Sea and the northern Baltic Proper. Ophelia 25:147-155

Thiel M, Ullrich N (2002) Hard rock versus soft bottom: the

Editorial responsibility: Matthias Seaman,

Oldendorf/Luhe, Germany fauna associated with intertidal mussel beds on hard bottoms along the coast of Chile, and considerations on the functional role of mussel beds. Helgol Mar Res 56:21-30

Tsuchiya M, Nishihira M (1985) Islands of Mytilus as a habitat for small intertidal animals: effect of island size on community structure. Mar Ecol Prog Ser 25:71-81

Tsuchiya M, Nishihira M (1986) Islands of Mytilus edulis as a habitat for small intertidal animals: effect of Mytilus age structure on the species composition of the associated fauna and community organization. Mar Ecol Prog Ser 31: 171-178

Tsuchiya M, Retière C (1992) Zonation of intertidal organisms and community structure of small animals associated with patches of mussel Mytilus edulis L. along the rocky coast of Dinard, Brittany, France. Bull Coll Sci Univ Ryukyus 54:47-81

Widdows J, Brinsley MD, Salkeld PN, Elliott M (1998) Use of annular flumes to determine the influence of current velocity and bivalves on material flux at the sedimentwater interface. Estuaries 21:552-559

Witman JD (1985) Refuges, biological disturbance, and rocky subtidal community structure in New England. Ecol Monogr 55:421-445

Submitted: March 28, 2008; Accepted: September 25, 2008 Proofs received from author(s): November 10, 2008 